\title{
Human Capital in Azerbaijan: Building Competitive Workforce Capacity for Industry 4.0
}

https://doi.org/10.21272/sec.5(2).58-69.2021

Latif Zeynalli, ORCID: https://orcid.org/0000-0001-5887-7946

Ph.D Candidate, Azerbaijan State University of Oil and Industry, Azerbaijan

\begin{abstract}
Human capital is one of the country's most significant economic metrics. Today, of course, the advancement of technology, the production of inventions, is a result of the human brain. It, in effect, naturally happens in countries with highly evolved human capital. This paper summarizes the arguments and counterarguments within the scientific discussion on the issue priorities of human capital development in Azerbaijan during the industrial revolution. The main purpose of the research is to identify and encourage the improvements in Industry 4.0 in Azerbaijan that would be essential for human capital, as well as to suggest a sustainable workplace outlook for current manufacturing businesses during the modern industrial revolution. The relevance of this scientific problem decision is that given the formation of new mechanisms of development on the eve of the 4th Industrial Revolution, these factors also have an impact on the development of human capital. Because the emergence of new professions during the 4th industrial revolution makes it necessary to form human capital in accordance with these professions. Investigation of the topic in the paper is carried out in the following logical sequence: introducton, literature review, research methodology, empirical findings and conclusions. We used some indicators expressed in the 2008-2017 Global Competitiveness Report of the Azerbaijan World Economic Forum to assess the findings. The object of research is the chosen country is Azerbaijan, because namely here, the development of human capital is one of the main goals of public policy. The paper presents the results of an empirical analysis regression, which showed that regression outcomes show that independent variables can explain 63.2 percent of the heterogeneity in higher education and training in Azerbaijan. Calculations of parameters indicate that any change of 1 percent in the independent variable will increase by 0.341 percent. The results of the study suggest that progressive reforms in Azerbaijan's higher education and training have had a major effect. To meet the requirements of the Fourth Industrial Revolution, spending on human capital must be increased. The results of the research can be useful for in the direction of formation of competitive human capital and creation of modern innovation space in the coming years.
\end{abstract}

Keywords: Azerbaijan, human capital, industry 4.0 revolution, innovation, competitive workforce, education training.

JEL Classification: E24, J24, O15.

Cite as: Zeynalli, L. (2021). Human Capital in Azerbaijan: Building Competitive Workforce Capacity for Industry 4.0. SocioEconomic Challenges, 5(2), 58-69. https://doi.org/10.21272/sec.5(2).58-69.2021.
Received: 22.05 .2021
Accepted: 22.06.2021
Published: 25.06 .2021 Copyright: (C) 2021 by the author. Licensee Sumy State University, Ukraine. This article is an open
access article distributed under the terms and conditions of the Creative Commons Attribution (CC BY) license (https://creativecommons.org/licenses/by/4.0/).

\section{Introduction}

Although the organization and management of human labor were initially known as the concept of personnel management, it later gave way to the concept of "human resource management" with the transformation of approaches to production, known as "clichés". In the last decade, however, human resource management has entered a qualitatively new phase, with the concept of "human capital management" being adopted. According to the human capital approach, companies, like other capital resources, consider their human resources as their strategic assets, not as a cost center, but as a strategic profit center. Economies that call human resources Human 
Capital, like other capital resources, makes a substantial investment in human capital, protects it in every way and sees it as one of the main means of gaining a competitive advantage.

By the definition of "Human development and its measurement" that originated at the end of the 20th century, economic growth cannot be defined simply as a rise in income, an improvement in employment prospects, and financial capital (Muradov, et al., 2019). "Human capital" is a crucial necessity for the creation and management of productive organizations (Meisenberg and Lynn, 2011). The development of human resources is a complex operation. The abilities learned at one point of the development cycle influence both the initial circumstances and the learning equipment at the next level. In modern days, economic growth becomes more focused on the creation of human resources. When the amount of highly skilled and highly trained citizens in the world rises, so do the strategic goals in the development of the nation as the country tries to generate more science-intensive goods. As a consequence, more and more citizens are spending in building human resources in emerging countries. The overall amount of spending on human resources is also rising in developed countries. Human capital is the number of existing assets in the skills and abilities of an individual that will produce profits in the future. It is possible to characterize human capital as a range of knowledge, skills, and abilities used in activities, processes, and services that contribute to stimulating economic development (Neeliah and Seetanah, 2016). While human capital is more apparent in education, it does not imply that it is only linked to education. It is likely that, for whatever reason, a person does not want to pursue his or her education and is more involved in music. In the future, he wants to make money in this area. So, if every hour a person spends on music from an early age takes his income to the future, that's his investment in "human capital." Only the money that an individual invests to buy a musical instrument is an expenditure in human resources. This is clear that it will be best for an artist to be trained in the related sector, but there are hundreds of people who excel in music without schooling. From this point of view, when a person participates in the art that he enjoys, he should be involved in improving it further, so that he may be developed as an individual value to society and himself. The idea of human capital has long roots in the history of economic thought. One of its first formulations is found in "Political Arithmetic" by W. Petty. Later it was reflected in the "Wealth of Nations" by A. Smith, the "Principles" of Marshall, the works of D. Ricardo, C.Marks, J. Mill, L. Walras, J. M. Clark, F. Liszt, G. D.Macleod, J. McCulloch, I. Thunen, P. Fisher, W. Farr, T. Whitstein, J. S. Walsh and many others. The emergence and formation of the concept of human capital in its modern form have become possible thanks to the work of T.Schulzt and G. Becker.

The concept of human capital is not new. Economists have used it as far back as Adam Smith in the eighteenth century. Recently, economists specializing in human capital theory have won the Nobel Prize; Gary Becker is perhaps the most well-known. The human capital analysis examines how people and culture make economic gains from investment in men. From the point of view of the economist, intellectual resources are expenditure on the development of knowledge and expertise (Phillips, 2005).

The term human capital originated with Theodore Schultz, an economist who is interested in the plight of underdeveloped countries in the world. He rightly argued that traditional economic concepts have not addressed this problem. He argued that improving the welfare of the poor did not depend on land, equipment, or energy, but rather on knowledge. Schultz, who won the 1979 Nobel Prize, described this qualitative aspect of economics as "human capital" by offering the following description: To consider all human abilities to be either innate or acquired. Each person is born with a specific set of genes that determine his or her innate ability. Attributes of acquired population efficiency, which can be measured and improved by sufficient expenditure, would be considered human capital (Schultz,1981). Okay, according to T. Schulz, both natural capital and skills are either inherent or learned. The growing person is born with an individual gene complex that decides his or her inherent human ability. According to G. Becker, intellectual resources are the pool of expertise, abilities, and motives that everybody has. Investments can involve schooling, the acquisition of technical knowledge, health security, geographical mobility, the quest for intelligence. The human capital theory assumes that individuals expect to be paid for their expenditure in intellectual resources, suggesting that citizens choose to increase their economic gains over their lifespan. The human capital theory was also initially formulated to describe fluctuations in workers' financial returns. Applied to business, this suggests that businessmen aim to earn positive gains on their 
projects equal to their human capital assets. The human capital of entrepreneurs should therefore be positively associated with a preference for venture scale and growth (Unger, et al., 2011).

The popular link between the terms 'human' and 'capital' is that each applies to intangible beings. 'Human' is a generic thing; as a term, it applies to a sort of actual person, which may even be modified to represent an individual's own personal identity. "Capital" applies to capital and to the production of value. To conclude that both person and capital are abstract phenomena is to imply a paradoxical situation in which there is in effect no observable 'human' or 'capital' even as all words are generally believed to indicate items about which there is empiric proof. Every word is a kind of meaning (Peers, 2015).

The definition of human capital, however, is much wider and includes the quality of education, the general health of the working population, and different types of training, such as on-the-job training or other forms of informal education. To date, for a large cross-section of economies, the inclusion of various aspects of human resources in a holistic calculation has proved to be intractable (Savvides and Stengos, 2009).

Human capital can be described in business terms as a combination of variables such as the following (Fitz-Enz, 2000):

- Characteristics that one takes to function: intelligence, strength, positive mood overall, efficacy, commitment.

- Ability to learn: ability, creativity, imagination, and what is sometimes referred to as "street smarts," skillful skills (or how to do things)

- Motivation for data and information sharing: team spirit and goal orientation.

The presumption that capacity is set at a very early age is another prevalent fallacy in the study of human resource policies. A more remedial interpretation of the skill (or rather the capacity) suggests that it is established in many learning circumstances and that early success, in effect, promotes more success (Heckman, 2002). A trained, innovative, enterprising, highly. a skilled individual is at the core of human capital. Human capital is the number of expenditures in expertise and abilities that will support the potential activities of a person (Zeynalli. L., 2017). In a new concept of human capital, people invest in their work as a set of features, trade-in life, experience, imagination, innovation, and resources. (Pasban and Nojedeh, 2016).

The economy of the world has entered into the Fourth Industrial Revolution today. Digitalization, the convergence of technology, and the removal of distinctions between the physical, digital and biological realms define it. In terms of size, design, and sophistication, the Fourth Industrial Revolution differs from all other human lives. An incredible technological breakthrough awaits us in the widest field, including artificial intelligence, robot cars, nanotechnology, biotechnology, and more. In this sense, to render the Industry 4.0 strategy a practice, it is important to follow a variety of criteria that are currently in effect, as well as integrated with the technology transition phase. One of them is the need to prepare people to work in the manufacturing sector through technology transfer (knowledge) (Silva, et al., 2019).

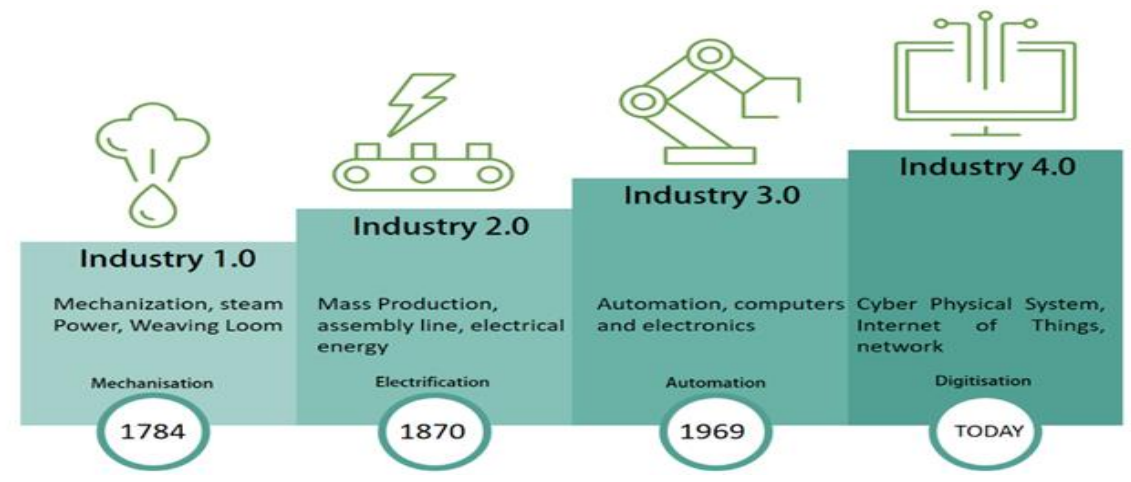

Figure 1. Stages of the industrial revolution

Source: WINIX Technologies, 2018. 
To find the definition of the Fourth Industrial Revolution, we must first go back in history and look at how other revolutions took place. The first industrial revolution mechanized production to some extent, using water and steam. Throughout the Second Industrial Revolution, society became familiar with technology and started industrial manufacturing. Eventually, the third industrial revolution (digital revolution) took place in the middle of the last century and, due to software and computers, citizens were able to simplify production. The most defining feature of this industrial revolution is its tempo, size, and systemic effect. The most positive promise of the Fourth Industrial Revolution is to make it better for humanity and to boost the standard of life. By implementing modern smart technologies, people can avoid accidents to some degree by learning about natural events in advance.

Throughout the agricultural period, the focus of development has been on land and on how to make it more competitive. During the industrial age, which dominated most of the first half of the twentieth century, the focus of development was on how productivity and income could be generated through the use of machinery. Throughout the information economy, development focuses on human experience and how intelligence is used to create a more competitive and effective environment. Any analyst called the information market a system of creativity controlled by a skill organization.

Table 1. Human capital perspectives

\begin{tabular}{|c|c|}
\hline Traditional review & Present review \\
\hline Human capital investment is perceived to be a expense & Human capital investment is used as a store of income. \\
\hline The position of the HR is viewed as support workers. & The position of the HR is viewed as a strategic partner. \\
\hline HR is interested in the creation of the allocation for HR. & $\begin{array}{l}\text { Top executives are constantly interested in the distribution of the } \\
\text { budget for HR. }\end{array}$ \\
\hline Human capital indicators rely on expenses and operations. & Metrics of human capital rely on performance. \\
\hline $\begin{array}{l}\text { Human capital indicators are established and managed by } \\
\text { HR alone. }\end{array}$ & $\begin{array}{l}\text { Top executives are interested in the creation and application of } \\
\text { indicators. }\end{array}$ \\
\hline $\begin{array}{l}\text { No attempt is taken to consider the return on expenditure } \\
\text { in intellectual resources. }\end{array}$ & $\begin{array}{l}\text { The usage of ROI has been an significant method for recognizing the } \\
\text { connection between cause and effect. }\end{array}$ \\
\hline $\begin{array}{l}\text { The assessment of intellectual resources depends on the } \\
\text { evidence at hand. }\end{array}$ & The assessment of human capital depends on the evidence provided. \\
\hline $\begin{array}{l}\text { The measurement of human capital is based on what GE } \\
\text { and IBM are measuring. }\end{array}$ & $\begin{array}{l}\text { The calculation of human capital is focused on what is required in the } \\
\text { enterprise. }\end{array}$ \\
\hline $\begin{array}{l}\text { HR systems are implemented without the requirement for } \\
\text { enterprise to be connected to them. }\end{array}$ & $\begin{array}{l}\text { Prior to introduction, HR systems are related to particular client } \\
\text { requirements. }\end{array}$ \\
\hline $\begin{array}{l}\text { Feedback is based on cumulative data on human capital } \\
\text { initiatives and ventures. }\end{array}$ & $\begin{array}{l}\text { Output is based on cumulative data on organizational resource systems } \\
\text { and initiatives. }\end{array}$ \\
\hline
\end{tabular}

Source: Meisenberg, G., \& Lynn, R. (2011). Intelligence: A measure of human capital in nations. The Journal of Social, Political, and Economic Studies, 36(4), 421.

In general, with the introduction of new technologies, unprecedented digital developments in all directions can reduce the role of the human factor in production and the economy. Countries that have not yet completely learned the Third Industrial Revolution should be ready to launch the Fourth Revolution again years later. As a consequence, the economic divide between developed and developing countries will expand. Industrial revolutions are typically complex, reactive, or completely disruptive. The 4th Industrial Revolution, unlike other revolutions, may result in the replacement of man by a few lines of computer code instead of the reinforcement and creation of man. The new industrial revolution will have the potential to open up unlimited opportunities for those who apply it in time. 


\section{Literature review}

It is clear that the properly structured activity of a corporation is a path to success. More than half of company success is professionally chosen workers and the maintenance of a healthy atmosphere for employee operation (Almasova-Huseynova, et al., 2016)

Getting equipped for the future is focused on the proper recognition of our technology processes today. The global economy has achieved such a high degree of growth in recent years that the country's economies are struggling to keep up with this progress. They must keep in mind that the technological developments that decide the course of potential progress are now with us, starting to invade all aspects of our lives. This is possible that we do not know to what degree potential developments will impact us, but what is obvious is that anyone that will not plan for the future will fall behind in growth and will be happy to stick to the corner of the industrial world. The Fourth Industrial Revolution has set in two gradual transformations. The first is a scientific one, where technologies such as artificial intelligence, digital reality, interactive reality, intelligent engineering, and robots are continually transforming our environment upside down, providing both new physical and cognitive capacities. The second transformation is the human one, and it may have more influence than the first in fact. Before they are applied to a business situation, human experience or skills are of little organizational importance. Value Add also continues to achieve the company's goals.

\section{Research methodology}

The paradigm is transitioning from share capitalism to stakeholder capitalism. Shared capitalism is an economic structure centered on a limited liability company that collects capital from shareholders. The business represents all partners of stakeholder capitalism. It covers clients, vendors, staff, owners, and local communities of the company. Throughout the age of Industry 4.0, recognizing that humans and machines are the agents completing each other is beginning to gain even more popularity nowadays (Bensghir, 2018).

For the company with an expectation to achieve company targets based on staff ability and their desire to the personal improvement of ability can be pointed out as the aspects of the key element in improving company assets and employees, and to increase productivity as well as sustain competitive advantage. The second segment of the implementation of human capital paying significant place in organizational development is to create the required environment for this purpose. It relates to training, education, and other professional programs aimed at growing an employee's level of expertise, skills, abilities, values, and social properties. It contributes to the happiness and success of the employee and ultimately performs the business an important pact (Rza-Guliyeva and Rustamov, 2016).

Since the advent of humanity, scientific innovation has become the guiding factor behind the growth of human civilization. Over time, the interests of economics researchers have developed in tandem with the development of technology. To date, this transition has been characterized by four significant strides forward, known as technological revolutions, triggered by new developments (Sima, et al., 2020). The Transformation of Industry 4.0 is distinguished by the crucial function played by the flexibility in arranging the exchange of information. The composition of the technical model of development has evolved from the model: information + technology + creativity, relating to the digital economy, to the model: human intellect + emerging software techniques + software + invention, in the age of Industry 4.0. At this point, the innovation of the person and the creation of human resources are the qualitative foundation of the nice. At Industry 4.0 level, it is important to adjust the education framework to the current technology needs of society; in these changing circumstances, only the information acquired can lead to the growth of Industry 4.0 and its stable progress (Kolesnichenko, E. A et al., 2019). Industry 4.0 is a transition driven by revolutionary technologies, where digitization and artificial intelligence are the focal points of efficiency growth (Schäfer, 2018).

The industry continues to rely on a small specialization, and the explanation for this appears to be A. Marshall says this is the "flow of knowledge" effect. Demand for 'human' skills-creativity, originality and effort, analytical reasoning, confidence and attention to detail, flexibility, resilience, creative problem solving, emotional intelligence, teamwork, social influence, and service orientation-will also grow. Not unexpectedly, for many 
businesses, their sustainable growth relies on the production of innovative and specialized goods, operation areas that utilize human skills, after an initial wave of automation to minimize labor costs.

In the latest topic of the Future of Jobs Report, the World Economic Forum (WEF) again touched on common awareness of the fronts that are in a better place to track the complexities of the workforce - managers, especially key human resources officers, several of the world's largest employers. They were asked to reflect on the latest developments in employment, skills, and trends in investing in human capital in different industries and regions. The new survey of the World Economic Forum, which contributed to comprehensive research in all nations, was regarded by a range of leading analysts as a declaration at the outset of the 4th Industrial Revolution. Throughout the coming years a lot of businesses may have to employ foreign employees, skilled contractors, to do their jobs. Others would have to delegate several activities. According to the study, workers may require different skills as collaboration with computers and humans continues to improve. As for the stated investment intentions of the companies surveyed, by 2022, 85 percent are likely or likely to expand their use of Big Data Analytics by users and organizations. Similarly, several businesses are expected or expect to extend their usage of technology such as the Internet of Things and the mobile and network development industries, while at the same time allowing heavy use of cloud infrastructure.

Industry 4.0 is a trend that is now upon us and, to maintain a strategic edge, companies need to adapt their behaviors to the evolving world. Developed countries are now experiencing disruptions triggered by industry 4.0 in their manufacturing ecosystems, and improvements are projected to accelerate across the globe in the next several years because economic revolutions are often driven by a country's technical advances. The areas impacted by the transition are not only important to the industrial climate, but would also have an effect on the nature of the duties of workers, and are likely to improve employees' prospects for the human resource (HR) career (Dhanpat, et al., 2020). There is a range of factors that impede the spread of Industry 4.0, and the human factor is of particular importance (Nagy, et al., 2018):

- Inadequate quality labor force

- Shortages between the workforce

- Old-style teaching

In the Smart Manufacturing and Industry 4.0 Transformation, individuals today have tremendous knowledge of how businesses can share their skills to make a difference. Therefore, the move to Intelligent Manufacturing and Industry 4.0 has the necessary components, including cyber-physical networks, the Internet of Things, the Internet of Services, and the Web of Data. New technologies have been applied by Smart Manufacturing and Industry 4.0 technologies such as Internet of Things (IoT), Industrial Internet (II), Cloud-based Manufacturing (C-BM) (Monostori, 2014), and Smart Manufacturing. This dream of digitally-driven production is widely embraced by the innovative theory of the Industry 4.0 Revolution (Gao, et al., 2015). The theory of human capital assumes that knowledge provides people with greater thinking skills, thereby improving their productivity and efficiency capacity to enhance operations (Phillips, 2005).

Table 2. Industry 4.0 skills portfolio

\begin{tabular}{|c|c|c|}
\hline Rank & Skill & Example \\
\hline 1 & Social skills & Negotiations, emotional intelligence, collaboration \\
\hline 2 & Cognitive skills & Data analysis, abstract thinking \\
\hline 3 & Personal/mental abilities & Decision making under pressure, persistence \\
\hline 4 & Process skills & Critical thinking and deductive reasoning \\
\hline 5 & System skills & Integrated decision making, entrepreneurial skills \\
\hline 6 & Technical skills & Programming and adapting to new technologies \\
\hline 7 & Content skills & Understanding ICT, active learning \\
\hline 8 & Intercultural skills & Working across cultures and geographies \\
\hline 9 & Resource management skills & Managing time and resources efficiently \\
\hline
\end{tabular}

Source: Eberhard, B., Podio, M., Alonso, A. P., Radovica, E., Avotina, L., Peiseniece, L., ... \& Solé-Pla, J. (2017). Smart work: The transformation of the labour market due to the fourth industrial revolution (I4. 0). International Journal of Business \& Economic Sciences Applied Research, 10(3). 
The creation of analytical and social skills that will allow workers to communicate with increasingly diverse communities and easily understand knowledge presented by human-machine interfaces is a core priority for potential workforce policy strategies. Table 1 offers a structure for understanding the general characteristics of professional employees working in the Industry 4.0 climate.

The concept of the "dark factory" (robotic devices do not need illumination to work), which has evolved as a consequence of technological initiatives over decades, has contributed to issues such as the phenomenon of the elimination of versatility in manufacturing, lack of efficiency and innovation in the workplace and the reduction of jobs. Following the changes introduced to Industry 4.0, a human component with a potential for flexibility, adaptability, innovation, logic, and decision-making that can hardly be substituted by automated systems is envisaged as a crucial and core role in future development processes (Frey and Osborne, 2017).

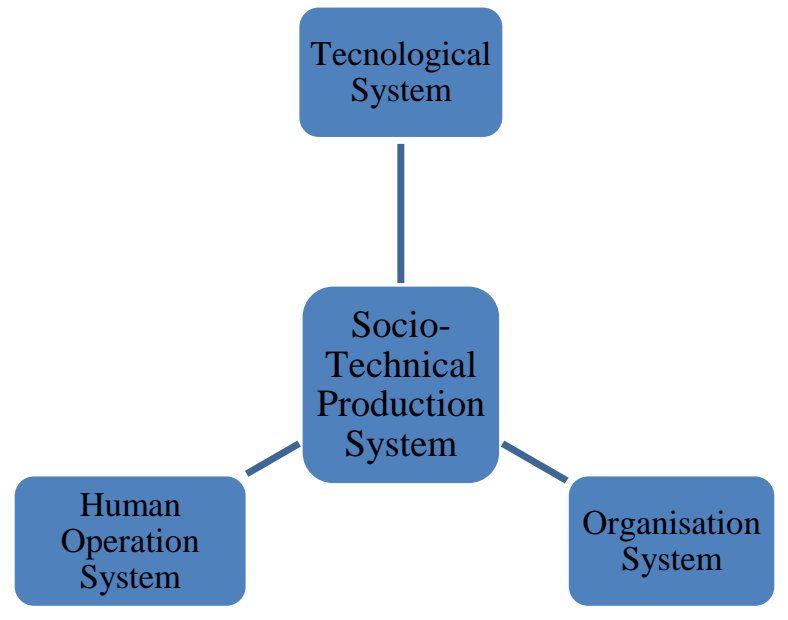

Figure 2. The illustration of the integration between human, technology and organization in IR 4.0

Source: Gan, J. L., \& Yusof, H. M. (2019). Industrial Revolution 4.0: the Human Resource Practices. International Journal of Recent Technology and Engineering (IJRTE), 8(3S2).

The Global Competitiveness Report of the World Economic Forum for 2019 also points to how countries are preparing for the 4th Industrial Revolution. The Global Competitiveness Index 4.0 system is divided into 12 key factors of profitability, or 'pills.' This puts a focus on conditions that will rise in value as the Fourth Industrial Revolution accelerates: human capital, agility, resilience, and innovation.

Figure 3. The Global Competitiveness Index 4.0 framework

\begin{tabular}{|c|c|}
\hline Enabling environment & Markets \\
\hline Pillar 1 & Pillar 7 \\
Institutions & Product market \\
\hline Pillar 2 & Pillar 8 \\
Infrastructure & Labour market \\
\hline Pillar 3 & Pillar 9 \\
ICT adoption & Pillar 10 \\
\hline Pillar 4 & Market size \\
\hline Macroeconomic stability & Innovation ecosystem \\
\hline Human capital & Pillar 11 \\
\hline Pillar 5 & Business dynamism \\
\hline Health & Pillar 12 \\
\hline Pillar 6 & Innovation capability \\
\hline
\end{tabular}

Source: The Global Competitiveness Report. (2019). World Economic Forum, 1-666. 
From the above, it can be inferred that improvements in the market for jobs in the workforce are anticipated in line with Industry 4.0. First of all, the average working-age is rising. Third, staff at the workplace are mixed in terms of race. Third, labor demand is growing faster than in previous periods. Such developments highlight the value of offering ongoing organizational assistance, technical programs, and recruitment to industrial enterprises. As a result, the development of job processes, duties, and obligations would eventually contribute to the enhancement of the skills expected by employees. In this regard, 'machine analysis' skills are essential since the most basic efficiency of workers must require increasingly dynamic processes and technology such as the Industry 4.0 climate, automation, interconnection, and interoperability between subsystems. It can be shown, a modern method to work production needs to be illustrated during the Fourth Industrial Revolution. In addition to the projected development as a consequence of technological transition, the schooling, renewable energy, treatment, leisure, and health sectors are anticipated to increase in emerging and industrialized countries. The role of technology users in important areas will increase significantly in 2022. These include researchers and physicists, tech and device designers, e-commerce and social networking experts, artificial intelligence and machine learning professionals, large data specialists, information security analysts, and robotics engineers. However, some sectors have tremendous promise and which have strong 'human' characteristics, such as customer service, advertising and marketing, education and development, people and culture, creative management, and organizational development. There are unique openings of success. In short, countries would need to have the best opportunities for innovation and entrepreneurship. It makes it really necessary to have a productive worker in the sector during the fourth industrial revolution.

\section{Empirical findings}

We used several indicators expressed in the 2008-2017 Global Competitiveness Report of the Azerbaijan World Economic Forum to assess the findings. In the table below, such metrics are mentioned.

Table 3. The Global Competitiveness Report 2008-2017 of Azerbaijan.

\begin{tabular}{|c|c|c|c|c|c|c|}
\hline Year & GCI & HPE & HET & LME & BS & I \\
\hline 2008 & 4.10 & 4.72 & 3.76 & 4.70 & 3.91 & 3.53 \\
\hline 2009 & 4.30 & 5.04 & 3.88 & 5.07 & 3.90 & 3.53 \\
\hline 2010 & 4.29 & 5.50 & 3.96 & 4.82 & 3.84 & 3.16 \\
\hline 2011 & 4.31 & 5.12 & 4.01 & 4.95 & 3.81 & 3.20 \\
\hline 2012 & 4.41 & 5.08 & 3.91 & 4.80 & 3.91 & 3.45 \\
\hline 2013 & 4.51 & 5.07 & 4.00 & 4.72 & 3.97 & 3.45 \\
\hline 2014 & 4.53 & 5.20 & 3.90 & 4.60 & 3.90 & 3.30 \\
\hline 2015 & 4.50 & 5.22 & 3.90 & 4.57 & 3.86 & 3.33 \\
\hline 2016 & 4.55 & 5.65 & 4.16 & 4.77 & 4.02 & 3.63 \\
\hline 2017 & 4.69 & 5.72 & 4.46 & 5.01 & 4.44 & 4.00 \\
\hline
\end{tabular}

Source: The Global Competitiveness Report. (2019). World Economic Forum, 1-666.

We would then aim to obtain a certain outcome by running a regression study in the SPSS to assess the effect of higher education and training on certain growth metrics separately.

Table 4. Descriptive Statistics

\begin{tabular}{|c|c|c|c|}
\hline & Mean & Std.Deviation & $\mathrm{N}$ \\
\hline Higher education and training & 3.994 & 0.19398 & 10 \\
\hline Labor market efficiency & 4.801 & 0.1667 & 10 \\
\hline Business sophistication & 3.956 & 0.18044 & 10 \\
\hline Innovation & 3.458 & 0.2428 & 10 \\
\hline GCI & 4.419 & 0.17071 & 10 \\
\hline
\end{tabular}

Source: The output of the statistical program IBM SPSS Statistics Version 25.

As can be seen from the above SPSS sentence, the findings represent the mean and standard deviation of the indicators. According to 10-year figures, the rate for higher education and employment is 3.9, although the standard deviation is 0.19 . 
Table 5. Correlations

\begin{tabular}{|c|c|c|c|c|c|c|}
\hline \multirow{5}{*}{ Pearson Corellation } & & HET & LME & BS & I & GCI \\
\cline { 2 - 7 } & HET & 1.000 & .437 & .867 & .683 & .745 \\
\cline { 2 - 7 } & LME & .437 & 1.000 & .359 & .379 &.-056 \\
\cline { 2 - 7 } & BS & .867 & .359 & 1.000 & .912 & .647 \\
\cline { 2 - 7 } & I & .683 & .379 & .912 & 1.000 & .471 \\
\cline { 2 - 7 } & GCI & .745 &.-056 & .647 & .471 & 1.000 \\
\hline
\end{tabular}

Source: The output of the statistical program IBM SPSS Statistics Version 25.

The correlation analysis shows that there is a stronger link between higher education and training and business sophistication and the Global Competitiveness Index (GCI). On the other hand, there is a weak correlation between labor market efficiency and GCI. The link between higher education and employment and labor market productivity and growth is 0437 and 0.683 , respectively. Besides, business sophistication and Innovation have a stronger correlation than other indicators, at 0.912 .

The figure also shows that the distribution is natural. For this research, the following econometric model was constructed:

$\ln \mathrm{HET}=\ln \beta 0+\ln \mathrm{LME}$

Where HET is Higher education and training, $\beta 0$ is constant and LME is Labor market efficiency

The description of the layout is shown in Figure 7. Because there are several independent variables, the square value of $\mathrm{R}$ needs to be taken into account. The square value of $\mathrm{R}$ is known to be 0.832 . Accordingly, 83.2 percent of the variance of the independent variables in our model in the dependent variable or the shift of schooling and training of Azerbaijan. We may assume that this model is an acceptable tool, as it describes a very significant part of the transition in education and training

Figure 6. Regression Plot

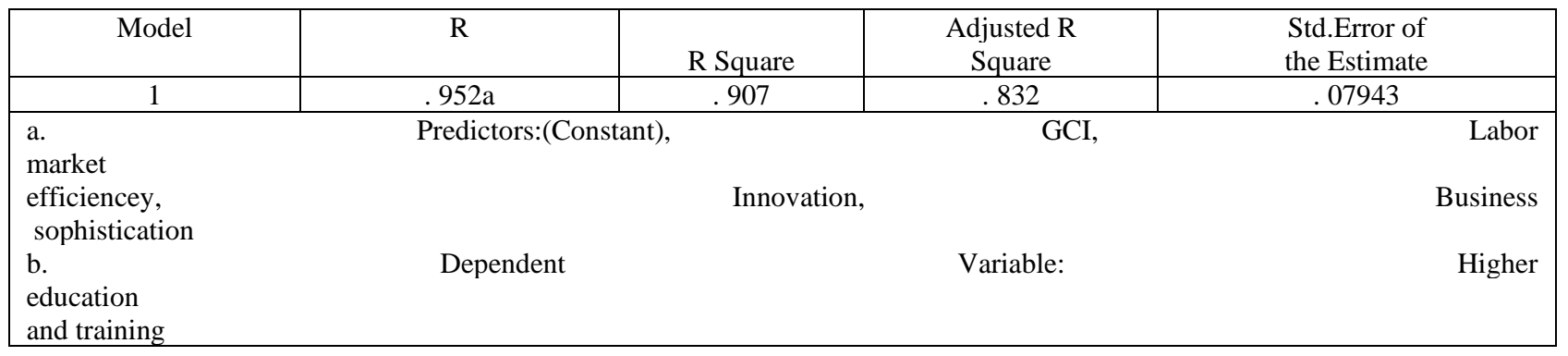

Source: The output of the statistical program IBM SPSS Statistics Version 25.

The variance analyses are shown in the next table (figure 8). We can see that the importance of the F value is very small (0.009), meaning that the equation of regression is statistically important.

Table 7. ANOVA

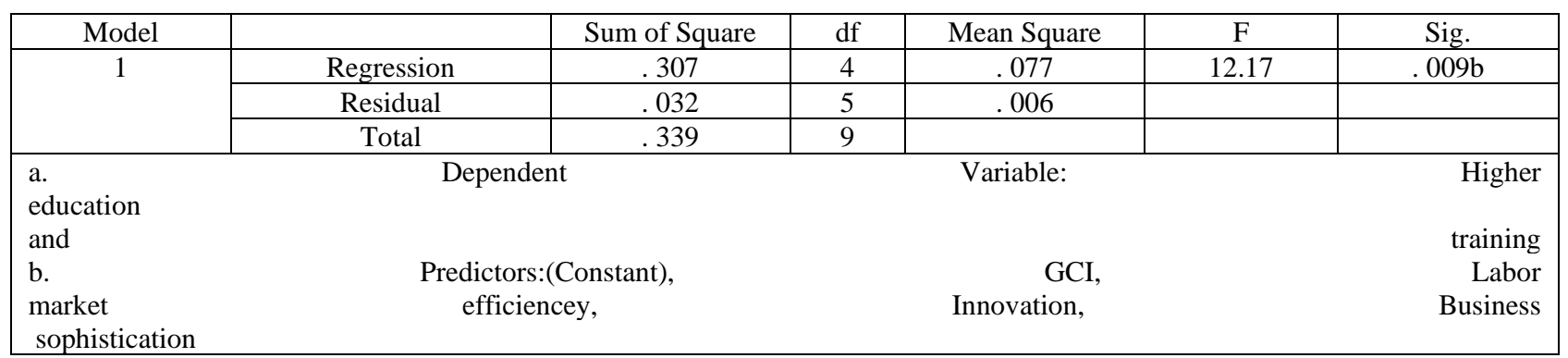

Source: The output of the statistical program IBM SPSS Statistics Version 25. 
In Table 9, parameter estimates for the regression equation are shown. We can write the approximate equation according to the results of the parameter estimates:

$\ln \mathrm{HET}=-2.239+0.341 \ln \mathrm{LME}$

Table 8. Parameter estimates

\begin{tabular}{|c|c|c|c|c|c|}
\hline \multirow{1}{*}{1} & Unstandardized B & Coefficents Std.Error & $\begin{array}{c}\text { Standardized Coefficents } \\
\text { Beta }\end{array}$ & $\mathrm{t}$ \\
\cline { 2 - 6 } & (Constant) & -2.239 & 1.112 & -2.013 \\
\cline { 2 - 6 } & $\begin{array}{c}\text { Labor market } \\
\text { efficiency }\end{array}$ & .341 & .186 & .293 & 1.832 \\
\hline
\end{tabular}

Source: The output of the statistical program IBM SPSS Statistics Version 25.

We can see from the above equation that productivity in Azerbaijan will increase by 0.341 percent for every 1 percent increase in the independent variable, labor market efficiency.

\section{Conclusions}

Human capital is one of the country's most significant economic metrics. Today, of course, the advancement of technology, the production of inventions, is a result of the human brain. It, in effect, naturally happens in countries with highly evolved human capital. This paper is an analytical analysis of the role of human resources in the fourth industrial revolution. To render the concept of Business 4.0 a fact, many conditions need to be fulfilled, one of which is the need to train citizens to work in industries. The study uses the World Economic Forum's Global Competitiveness Report on Azerbaijan for analysis for the period 2008-2017. A regression model is a model used in this study. Regression outcomes show that independent variables can explain 63.2 percent of the heterogeneity in higher education and training in Azerbaijan. For the $\mathrm{F}$ value, the degree of insignificance implies that the equation of regression is statistically relevant. Calculations of parameters indicate that any change of 1 percent in the independent variable will increase by 0.341 percent. The results of the study, therefore, suggest that progressive reforms in Azerbaijan's higher education and training have had a major effect. To meet the requirements of the Fourth Industrial Revolution, spending on human capital must be increased.

Funding: self-funded.

Author contribution: conceptualization: Latif Zeynalli; data curation: Latif Zeynalli; formal analysis: Paul F. Gentle; funding acquisition: Latif Zeynalli; investigation: Latif Zeynalli; methodology: Latif Zeynalli; project administration: Latif Zeynalli; resources: Latif Zeynalli; software: Latif Zeynalli; supervision: Latif Zeynalli; validation: Latif Zeynalli; visualization: Latif Zeynalli; writing - original draft: Latif Zeynalli; writing - review \& editing: Latif Zeynalli.

\section{References}

1. Muradov, A., Hasanli, Y., \& Musayeva, F. (2019). Estimation of the education influence on the population income, 37th International Coneference on Economic and Social Development, MPRA Paper No. 94089, 111. Available at: [Link].

2. Savvides, A., \& Stengos, T. (2020). Human capital and economic growth. Stanford University Press. [CrossRef].

3. Peers, C. (2015). What is Human Capital Theory? Marking a transition from industrial to postindustrial education. Open Review of Educational Research, 2(1), 55-77. [CrossRef].

4. Eberhard, B., Podio, M., Alonso, A. P., Radovica, E., Avotina, L., Peiseniece, L., ... \& Solé-Pla, J. (2017). Smart work: The transformation of the labour market due to the fourth industrial revolution (I4. 0). International Journal of Business \& Economic Sciences Applied Research, 10(3), 47-66. Available at: [Link].

5. Frey, C. B., \& Osborne, M. A. (2017). The future of employment: How susceptible are jobs to computerization? Technological forecasting and social change, 114, 254-280. [CrossRef]. 
6. Gao, R., Wang, L., Teti, R., Dornfeld, D., Kumara, S., Mori, M., \& Helu, M. (2015). Cloud-enabled prognosis for manufacturing. CIRP annals, 64(2), 749-772. [CrossRef].

7. Meisenberg, G., \& Lynn, R. (2011). Intelligence: A measure of human capital in nations. The Journal of Social, Political, and Economic Studies, 36(4), 421. Available at: [CrossRef], [Link].

8. Fitz-Enz, J. (2000). The ROI of human capital: Measuring the economic value of employee performance. AMACOM Div American Mgmt Assn. Available at: [Link].

9. Phillips, J. J. (2005). Investing in your company's human capital: Strategies to avoid spending too little--or too much. Amacom Books. Available at: [Link].

10. Phillips, J., \& Phillips, P. (2015). High-impact Human Capital Strategy: Addressing the 12 Major Challenges Today's Organizations Face. Amacom. Available at: [Link].

11. Heckman, J. J. (2002). Invest in the Very Young. Available at: [Link].

12. Gan, J. L., \& Yusof, H. M. (2019). Industrial Revolution 4.0: the Human Resource Practices. International Journal of Recent Technology and Engineering (IJRTE), 8(3S2). Available at: [Link].

13. Nagy, J., Oláh, J., Erdei, E., Máté, D., \& Popp, J. (2018). The role and impact of Industry 4.0 and the internet of things on the business strategy of the value chain - the case of Hungary. Sustainability, 10(10), 3491. [CrossRef].

14. Kolesnichenko, E. A., Radyukova, Y. Y., \& Pakhomov, N. N. (2019). The role and importance of knowledge economy as a platform for formation of industry 4.0. In Industry 4.0: Industrial Revolution of the 21st Century (pp. 73-82). Springer, Cham. [CrossRef].

15. Maguire, K. (2016). Lean and IT - working together? An exploratory study of the potential conflicts between lean thinking and the use of information technology in organisations today. In Understanding the lean enterprise (pp. 31-60). Springer, Cham. [CrossRef].

16. Pasban, M., \& Nojedeh, S. H. (2016). A Review of the Role of Human Capital in the Organization. Procediasocial and behavioral sciences, 230, 249-253. [CrossRef].

17. Monostori, L. (2014). Cyber-physical production systems: Roots, expectations and R\&D challenges. Procedia Cirp, 17, 9-13. [CrossRef].

18. Neeliah, H., \& Seetanah, B. (2016). Does human capital contribute to economic growth in Mauritius? European Journal of Training and Development. [CrossRef].

19. Dhanpat, N., Buthelezi, Z. P., Joe, M. R., Maphela, T. V., \& Shongwe, N. (2020). Industry 4.0: The role of human resource professionals. SA Journal of Human Resource Management, 18, 11. [CrossRef].

20. Petrov, V., Ćelić, Đ., Uzelac, Z., \& Drašković, Z. (2020). Specific influence of knowledge intensive and capital intensive organizations on collaborative climate and knowledge sharing in SMEs. Strategic Management-International Journal of Strategic Management and Decision Support Systems in Strategic Management, 25(1). Available at: [Link].

21. Schäfer, M. (2018). The fourth industrial revolution: How the EU can lead it. European View, 17(1), 5-12. [CrossRef].

22. Schultz, T. W. (1981). Investing in people. Berkeley. University of California Press. [CrossRef].

23. Sekaran, U. (2000). Research methods for business. New York: John Wiley \& Sons, Inc. Available at: [Link].

24. Simas, K., \& McCarrey, M. (1979). Impact of recruiter authoritarianism and applicant sex on evaluation and selection decision s in a recruitment interview analogue study. Journal of Applied Psychology, 64, 483-491. [CrossRef].

25. World Economic Forum. (2018). The future of jobs report 2018. Geneva: World Economic Forum, 1-147. Available at: [Link].

26. The Global Competitiveness Report. (2019). World Economic Forum, 1-666. Available at: [Link].

27. Bensghir, T. K., Türen, U., \& Y1lmaz, Y. (2018). How a workforce in industry 4.0 era? Labor 4.0, In Industry 4.0 from the MIS Perspective, Chapter 5, pp. 67-80. [CrossRef].

28. Unger, J. M., Rauch, A., Frese, M., \& Rosenbusch, N. (2011). Human capital and entrepreneurial success: A meta-analytical review. Journal of business venturing, 26(3), 341-358. [CrossRef].

29. Silva, V. L., Kovaleski, J. L., \& Pagani, R. N. (2019). Technology transfer and human capital in the industrial 4.0 scenario: A theoretical study. Future Studies Research Journal: Trends and Strategies, 11(1), 102-122. [CrossRef]. 
30. Sima, V., Gheorghe, I. G., Subić, J., \& Nancu, D. (2020). Influences of the industry 4.0 revolution on the human capital development and consumer behavior: A systematic review. Sustainability, 12(10), 4035. [CrossRef].

31. WINIX Technologies (2018). INDUSTRY 4.0: The Digital Technology Transformation, BEJCZY, 43-48. Available at: [Link].

32. Zeynalli, L. (2017). İnsan kapitalı anlayışına müqayisəli yanaşmalar, AMEA Íqtisadiyyat İnstitutu "Elmi asarlar" jurnall [Comparative approaches to the concept of human capital, Institute of Economics of ANAS Scientific works journal], N3, 1-7. Available at: [Google Scholar], [Link].

33. The output of the statistical program IBM SPSS Statistics Version 25. Available at: [Link].

34. Rza-Guliyeva, L.R., \& Rustamov, R.B. (2016). Training process contribution in engineering for human capital development. IJTPE, Issue 26, Vol 8, No 1. Available at: [Link].

35. Almasova-Huseynova, N.K., Babayeva, N.A, \& Rustamov, R.B. (2016). Contribution and Advances of The Key Performance Indicators in Human Resources Management. IJTPE, Issue 27, Vol 8, No 2. Available at: [Google Scholar], [Link]. 